\title{
TRANSPORT COSTS AND ECONOMIC GROWTH IN A BACKWARD ECONOMY: THE CASE OF PERU, $1820-1920 *$
}

LUIS FELIPE ZEGARRA

CENTRUM Católica, Pontificia Universidad Católica del Perú ${ }^{\text {a }}$

\begin{abstract}
This paper analyses the system of transportation and discusses the effect of geography and transport infrastructure on transport costs and economic growth in Peru during the $19^{\text {th }}$ and early $20^{\text {th }}$ centuries. Using primary and secondary sources, I find that geography imposed difficult transport challenges on Peruvians during this period. There were no navigable rivers in coastal and highland regions, railroads were scarce and most roads were inadequate for wagons, sometimes even for horses and mules. As a result, transport costs were extremely high, which constituted a barrier to trade, reduced gains from specialisation and retarded economic growth. Therefore, high transport costs seem to be one important factor in explaining the low income levels of Peru in the early $20^{\text {th }}$ century in spite of the country's large endowments of natural resources.
\end{abstract}

Keywords: transportation, railroads, Peru, Latin America

JEL Code: N70, N76, R40

* Received 1 September 2010. Accepted 21 June 2011. I appreciate the comments and suggestions of the three anonymous referees and am grateful to the staff of the National Library of Peru, the Library of the Pontificia Universidad Católica del Perú and the Library of the Municipality of Lima for their help and assistance during the process of data collection.

a Professor of CENTRUM Católica, The Business School of Pontificia Universidad Católica del Perú. lfzegarrab@pucp.edu.pe 


\section{RESUMEN}

Este artículo analiza el sistema de transporte y discute el efecto de la geografía y de la infraestructura de transporte en los costos de trasporte y el crecimiento económico en el Perú durante el siglo XIX y principios del siglo $\mathrm{XX}$. Usando fuentes primarias y secundarias, mostramos que la geografía impuso dificultades severas a los peruanos durante este período. El Perú no tuvo ríos navegables en la costa y en la sierra, hubo pocos ferrocarriles, y la mayor parte de los caminos eran inadecuados para carretas, incluso para caballos y mulas. Como resultado, los costos de transporte fueron extremadamente altos, lo que representó una barrera al comercio, redujo las ganancias por especialización y afectó el crecimiento económico. Por lo tanto, los altos costos de transporte parecen ser uno de los factores que explican los bajos niveles de ingreso de los peruanos a principios del siglo XX a pesar de sus grandes dotaciones de recursos naturales.

Palabras clave: transporte, caminos, Perú, América Latina

\section{INTRODUCTION}

In a world with gains from specialisation, transport costs may reduce the benefits of trade and retard economic growth ${ }^{1}$. Gallup et al. (1999), for example, found that coastal regions and those linked to coasts by oceannavigable waterways are strongly favoured in development in comparison with their hinterlands. Other articles also indicate that geography and transport costs affect trade and economic growth (Rousslang and To 1993; Eaton and Kortum 2002; Overman et al. 2003).

Historical evidence has been useful for analysing the economic effects of transport costs and technological innovations in transportation over long periods of time. In particular, the economic impact of railroads in the $19^{\text {th }}$ and early $20^{\text {th }}$ centuries has received much attention in the literature. Rostow (1962), for example, indicated that «the introduction of the railroad has been historically the most powerful single initiator of take-offs. It was decisive in the United States, Germany and Russia... (Rostow 1962, p. 302). Fremdling (1977), Price (1975) and Metzer (1974) also support the hypothesis that railroads played an important role for economic growth in Germany, France and Russia, respectively. Fogel (1962, 1964, 1979), however, argues that pre-rail modes of transportation in the United States were not necessarily

1 Increasing returns and horizontal specialisation, as well as vertical specialisation, may allow us to explain why transport costs reduce trade. 
associated with high transport costs, and therefore the construction of railroads in the $19^{\text {th }}$ century did not yield large social savings ${ }^{2}$.

In the case of Latin America, historical studies support the hypothesis that transportation costs were high in the pre-rail era and that the construction of railroads led to large social savings. Coatsworth (1979) indicates that in Mexico, before the railroad, waterways were not available in the habitable regions ${ }^{3}$, and thus freight was transported by wagon or on the backs of animals and men. The construction of railroads then reduced time and money transport costs, increasing trade and market integration (Dobado and Marrero 2005). Similarly, for Brazil, Leff (1972) and Summerhill (2005) indicate that prior to the construction of railroads, waterways were not widely used for transportation and the conditions of the terrain were poor ${ }^{4}$. As a result, transport costs from the agricultural regions to the largest markets were high. In addition, McGreevey (1971) and Hoernel (1976) also indicate that railroads played an important role in reducing transport costs and promoting economic growth in Colombia and Cuba, respectively.

Overall, it seems that prior to railroads, the availability of waterways provided a low cost mode of transportation. Transportation in wagons or on the backs of animals and men was more expensive. The impact of railroads on transport costs depended on the existence of waterways: if waterways were not available, the impact of railroads on transportation costs was large.

For Peru, some studies have analysed the role of transportation costs in the mining sector in the Central Andes and the interaction between the railroad and the traditional system of mules and llamas. According to Miller (1976), railroads played an important role for the mining sector in the central highlands of Peru but yielded small effects in other sectors, in particular agriculture. More recently, Contreras (2004) and Deustua (2009) also indicated that the construction of railroads facilitated the expansion of mining production, especially copper, in the Central Andes 5 .

2 Fishlow (1965), Hawke (1970) and Vamplew (1971) also support the idea that the social savings of railroads in the United States and some European countries were not very large. Similarly, Crafts and Mulatu (2006) indicate that falling transport costs before World War I had no major effect on the location of industry in Great Britain.

${ }^{3}$ Coatsworth (1979) indicates that Mexico did not have a river system suitable for use in transportation, and that most of the population and economic activity was located too far from the two coasts to use the sea as a means of communication.

4 Leff, for example, indicates that «Brazil's large hinterland did not have an extensive network of navigable waterways in the habitable areas comparable to the Mississippi and Great Lakes systems in the United States. Man-made transportation facilities were also noticeably lacking.» Leff (1972, p. 490). More recently, Summerhill (2005) also indicates that Brazil was deficient in transport facilities prior to the construction of railroads, with the exception of settlements near to the coast. Social savings from railroads were then large. In addition, unlike Summerhill (2005), Mattoon (1977) indicates that road conditions in Sao Paulo in the $19^{\text {th }}$ century were totally inadequate.

5 These studies indeed represent a contribution to understanding the impact of transport costs on the Peruvian economy. However, the literature lacks formal testing of the impact of transport innovations on economic growth. 
In this article, I examine the system of transportation in the $19^{\text {th }}$ and early $20^{\text {th }}$ centuries in Peru and analyse the effect of geography and transport infrastructure on transport costs, trade and economic growth during this period. The main objective of this study is to explore to what extent the transportation system of Peru contributed to the slow growth of the Peruvian economy during this period. This article is one of the few studies on the history of transportation in Peru and may help to understand the impact of geography and transport infrastructure on economic growth in a backward economy.

The study of transportation in Peru for this period is crucial for explaining the sluggish record of economic growth of this country. Peru is a special case, because it had a poor economic performance in spite of its favourable factor endowments. Contemporary observers described the abundance of natural resources, especially agricultural and mineral (Ledesma and Bollaert 1856; Markham 1874). In spite of the abundance of natural resources, in the early $20^{\text {th }}$ century, income levels of Peruvians were among the lowest in the region. High transport costs may constitute one possible explanation for the sluggish economic performance of Peru during this period.

The structure of the paper is as follows: Section 2 describes the geography, transport infrastructure and modes of transportation in the $19^{\text {th }}$ and early $20^{\text {th }}$ centuries. Section 3 reports some estimates on freight rates for using roads, railroads and the sea. Section 4 reports some estimates on time costs for the different modes of transportation. Section 5 discusses the possible effects of transportation costs on trade and economic growth in Peru during this period. Section 6 concludes the paper.

\section{ROADS, RAILROADS AND WATERWAYS}

In this section, I will provide an overview of the geography, transport infrastructure and modes of transportation of Peru during the $19^{\text {th }}$ and early $20^{\text {th }}$ centuries. As I will show, geography and the lack of infrastructure imposed severe obstacles to transportation during this period.

On the coast, geography and weather generated great challenges for transportation. The coast was largely constituted by large plains of sand ${ }^{6}$, which made the traction of wheels and even the work of horses and mules very difficult. These difficulties made journeys seem longer than they were ${ }^{7}$. Moreover, the heat in the desert could be deadly for the traveller and his horse, which meant that travellers preferred to travel at night in order to avoid the heat, although they ran the risk of straying off course when there

\footnotetext{
6 Stevenson (1825) indicates that the Lima-Trujillo route in the north of Peru was 108 leagues (around 370 miles), of which 88 leagues were sandy (Stevenson 1825, p. 113, Vol. II).

7 In 1873, for example, Raimondi indicated that the distance between Pativilca and Huarmey on the northern coast of Peru was 16 leagues, but most people thought it was 25 leagues (Raimondi 2006, p. 114).
} 
was no moonlight ${ }^{8}$. Freight was carried in wagons or directly on the backs of horses and mules (Deustua 2009). Horses were faster than mules in regular conditions. However, in the extreme conditions of the sandy, dry Peruvian deserts, mules were probably better than horses 9 . Even on the Lima-Callao route, traffic was «unthinkable without mule trains» (Waszkis 1993, p. 137).

The sea became an alternative means of transportation for coastal towns. With the introduction of steam navigation in the 1840s, travel along the coast was not affected by ocean currents and wind, and travellers enjoyed a faster and safer mode of transportation ${ }^{10}$. Coastal towns could then engage in trade by using the sea as a means of transportation. However, navigation faced some difficulties. For instance, with the exception of Callao, the main Peruvian port, the other coastal ports lacked proper installations to facilitate trade: they were simply natural ports (Contreras 2004) ${ }^{11}$.

In the highlands, geography and inadequate transport infrastructure made transportation even more difficult than on the coast ${ }^{12}$. Long, steep ascents, deep canyons, almost vertical hillsides and narrow roads made transportation

8 Tschudi (1847) considered transportation along the Peruvian coast as difficult, tedious and dangerous. In his words, "the roads lead through plains of sand, where often not a trace of vegetation is to be seen, or a drop of water to be found for twenty or thirty miles. It is found desirable to take all possible advantage of the night, in order to escape the scorching rays of a tropical sun; but when there is no moonlight, and above all, when clouds of mist obscure the directing stars, the traveler runs the risk of getting out of his course, and at daybreak, discovering his error, he may have to retrace his weary way. This extra fatigue may possibly disable his horse, so that the animal cannot proceed further. In such an emergency a traveler finds his life in jeopardy; for should he attempt to go forward on foot he may, in all probability, fall a sacrifice to fatigue and thirst» (Tschudi 1847, p. 138).

9 The mule was the "camel of the desert»: the endurance of mules when tired and with limited food supplies was extraordinary (Tschudi 1847, pp. 205-206).

10 «Even in sailing vessels voyages from south to north can be conveniently performed in consequence of the regularity of the trade wind.» (Tschudi 1847, p. 207).

11 In 1826 Callao was one of the few ports with proper installations for disembarking (Denegri 1976). In the 1920s, one century later, most coastal ports still lacked proper infrastructures. Jones (1927) indicated that out of the approximately thirty Peruvian seaports, only nine major ports handled exports and imports, and only four had fair harbors. Most ports only had «... open roadsteads unprotected from the winds and the ocean swell. As a result steamers usually anchor a mile or more off shore, and discharge or receive freight and passengers by means of lighters and launches, a slow and rather inefficient means of transfer» (Jones 1927, p. 24).

12 De Tschudi (1847) indicates that «all roads running from the coast to the Sierra, present a similarity of character. Taking an oblique direction from the margin of the coast, they run into one or other of the fan-shaped Cordillera valleys, all of which are intersected by rivers. Following the course of these rivers, the roads become steeper and steeper, and the valleys soon contract into mere ravines, terminating at the foot of the Cordillera ...» (Tschudi 1847, p. 255). In addition, in both coastal and highland regions, roads did not follow straight lines. The absence of bridges in some regions increased distances, since a traveller had to ride longer distances to find a safe way of crossing a river. For example, Raimondi indicated that although the distance in a straight line between the hacienda Pucalá and Pátapo in the north of Peru is only one and a half leagues, the presence of rivers and the lack of roads made it necessary to complete 5 leagues (Gómez and Bazán 1989). In addition, roads going around mountains also went up and down. Dávalos y Lissón (1919) indicates that roads that in a straight line were 100 kilometers long and had slopes of 3-6 per cent, ended up being 120 or 140 kilometers long with gradients of even 30 per cent. 
very difficult and almost impeded the use of the wheel. In the 1890s, Ernst Middenford observed that the geography of the Andes was never as complex as in Peru. The terrain was rarely flat, with the exception of the plateau of Titicaca and the valleys of Jauja and Vilcanota in the most populated regions (Middenford 1974, p. 10, Vol. III). Deep precipices and narrow roads made travel very dangerous. Roads were, in fact, so narrow that in some places two mules could not pass at the same time. In addition, during the rainy season (December-April), communication could be completely halted ${ }^{13}$.

In the highlands, freight was carried on the backs of mules and llamas. Mules had some advantages and disadvantages in comparison to llamas. One of the advantages of mules is that they could carry up to 300 pounds, whereas llamas could not carry more than 125 pounds, and even 100 pounds was usually considered a full load (Hills 1860, p. 101). Mules were then more appropriate for carrying heavy items. In addition, mules were faster than llamas: mules could cover as many as 35 miles per day, whereas llamas could only manage 15 miles at the most. Finally, mules could stand the heat of the coastal desert, whereas llamas could not. For journeys to or from the coast, then, mules were required for at least part of the route. On the other hand, llamas were better suited than mules for the difficult terrain and weather of the Andes ${ }^{14}$, and did not require much care since they were mostly fed from any herbage, which lowered their maintenance costs (Cisneros 1906, p. 124).

As a result of the differences between mules and llamas, mules were better for transporting heavy cargo on long journeys. Llamas were better for transporting smaller amounts of freight on short journeys in the highlands. In mining, for example, prior to the construction of the Central Railway, llamas were better for transporting minerals from a large number of mines in the Central Andes to the main mining haciendas where the minerals were

13 In addition, from May to November, banditry could also interrupt communication (Contreras 2004, pp. 76-77). Testimonies of travellers are quite illustrative. For instance, Wortley (1851) described the roads between the coast and the highland and indicated that «... the elevated plateau and table-lands, separated by deeply-embosomed valleys, and the gigantic mountains that intervene between the coast and the table-land, render travelling tedious and difficult. Roads and bridges, in many parts, are entirely wanting; and in places where rude and scarcely-distinguishable paths are found, they lie along the perilous edges of overhanging and rugged precipices, perpendicularly steep; and these tracks, moreover, are almost always so dangerously narrow, that the surefooted mule can alone tread them with any security ...» (Wortley 1851, pp. 244-245, Vol. III). Other travellers also indicated that roads in the highlands made the journey dangerous and exhausting. Consider, for example, Manuel Pardo's journey from Lima to Jauja in the 1850s (Essay «Estudios sobre Jauja», published as part of the book by McEvoy 2004, pp. 98-99), and Stevenson's journey from Lima to Cajatambo in the 1820s (Stevenson 1825, pp. 24-26, Vol. II).

14 Contemporary travellers were aware of these differences between mules and llamas. Hills (1860), for example, indicated that a llama "has spongy hoofs and claws, which enables him to pass over beds of ice with ease, and is well protected by his fleece from any cold to which he may be exposed» (Hills 1860, p. 101). Moreover, Cisneros (1906) observed that llamas could live in places where mules would die of hunger and cold. In addition, Tschudi (1847) pointed out that llamas could carry freight from places where the slopes were so «steep that neither asses nor mules can keep their footing» (Tschudi 1847, p. 308). 
FIGURE 1

RAILROAD LENGTH (IN MILES)

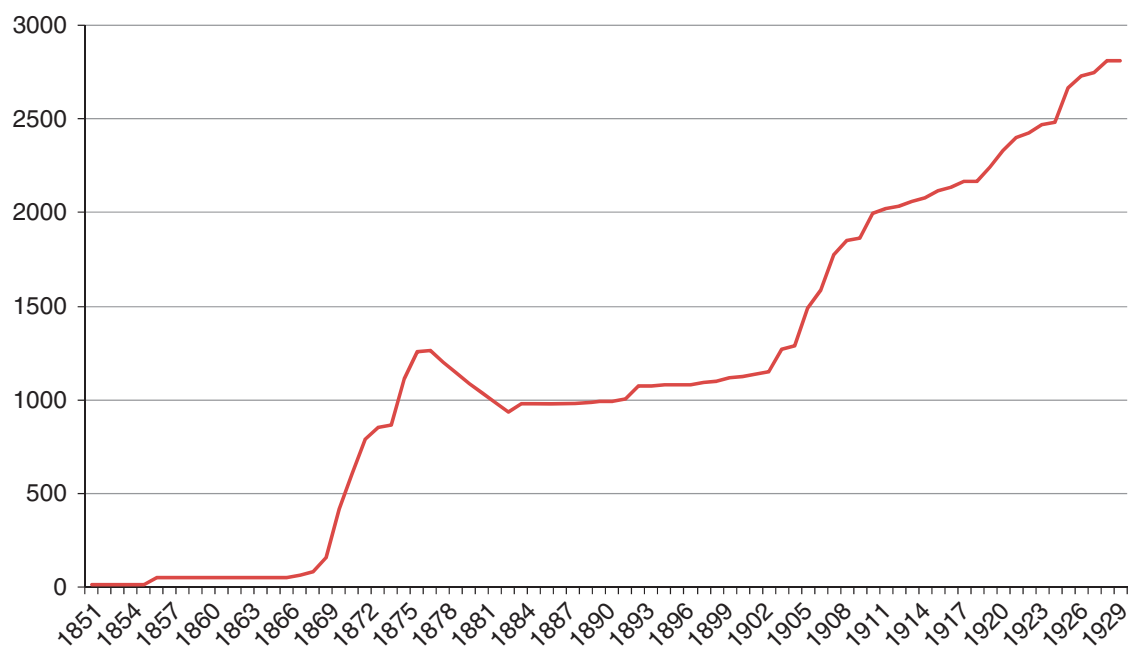

Source: Extracto Estadístico (1939).

concentrated, whereas mules were used for transporting minerals from those haciendas to Callao. On the coast, mules had to be used for even short journeys because llamas could not stand the heat in the sandy deserts.

One important drawback of Peru's topography is that rivers were not navigable in the habitable regions. Rivers flowed from the highlands to the Pacific coast, but they were not appropriate for navigation. Navigable rivers existed only in the jungle, which was mostly uninhabited ${ }^{15}$. Jones (1927) indicated that the lack of navigable rivers imposed enormous trade handicaps. "... No large navigable rivers offer routes into the interior and other means of entering the mountain zone are not easily provided ${ }^{16}$.»

Peruvians could also use railroads for transportation from the mid-19 century, but only for a few routes. Railroads were built from the 1850s, starting with the Lima-Callao railroad. The abundance of fiscal revenues in the $1850 \mathrm{~s}$ and 1860s allowed the government to expand the railway network (Figure 1). The length of the railway system increased from 60 miles in 1865 to 415 miles in 1870 and 1,113 miles in 1875. However, the decline in guano exports from the mid-1870s, the defeat in the War of the Pacific (1879-1883) and the consequent economic crises in the 1880 s and 1890 s paralysed railroad construction.

15 Only 4 per cent of the Peruvian population lived in the jungle.

16 «Between latitudes 5 degrees and 35 degrees south no pass in the Andes lies at an elevation of less than 11,000 feet. The trade handicap because of this situation is enormous ...» (Jones 1927, p. 151). 
The length of the railway system actually declined to 937 miles in 1883 and then increased to only 993 miles in 1890 and 1,118 miles in 1900.

A large number of towns were not connected by railroads in the early $20^{\text {th }}$ century (Figure 2). Dávalos y Lissón (1919) indicated that, according to a study by the engineer Tizón y Bueno, in the 1910s there were around 10,000 towns in Peru and that only 300 of them were connected by railroad. Similarly, Milstead (1928) indicated that railroad infrastructure was very deficient not only in the highlands, but also on the coast. According to Milstead, in the early 1920s primitive transportation facilities persisted in around 85 per cent of the country. Only 2,018 miles of steam railroads and 100 miles of street and interurban lines were in operation in 1924. Although some railways had been constructed in the 1850s, there was no integrated railway network (Milstead 1928, p. 68). Most towns depended largely on the traditional system of mules and llamas.

A comparison with other countries indicates that Peru had a relatively low level of railway coverage. In 1913, Peru only had 0.7 miles of railway track per 1,000 inhabitants. In contrast, the corresponding figure for Argentina was 4.3 miles. Other countries with at least 1 mile of railway track per 1,000 inhabitants were Brazil, Chile, Costa Rica, Cuba, Mexico, Panama and Uruguay ${ }^{17}$.

Therefore, geography and the lack of proper transport infrastructure imposed challenges on Peruvians in the $19^{\text {th }}$ and early $20^{\text {th }}$ centuries. Transportation along the coast and in the highlands was a difficult task. Several sources largely agree on the difficulties of travelling in the arid sandy desert or the steep Andes Mountains, and on the lack of proper port installations and of navigable rivers in the habitable regions. The construction of railroads, which started in the mid- $19^{\text {th }}$ century, probably made transportation faster and less costly. However, by the early $20^{\text {th }}$ century only a few miles had been built. In these circumstances, time and money transport costs for most Peruvians must have been high.

\section{FREIGHT RATES}

This section reports some estimates of freight rates for overland and sea transportation ${ }^{18}$. As indicated previously, the geography and transport infrastructure in Peru imposed some difficulties on transportation. Freight rates, then, must have been high ${ }^{19}$.

17 These figures are from Bulmer-Thomas (2003)

18 All figures are in 1,900 soles. The sol was the Peruvian currency from 1863 . Prior to 1863 , Peruvians used the peso. However, the specie content of the peso was the same as the specie content of the sol. Since prices varied over this period, I deflacted freight rates using a price index. The sources for the price index are from Gootenberg (1990) and Quiroz (1993).

19 This section only deals with freight rates. However, data on passenger fares yield similar conclusions: the traditional system of animal transportation was more costly than steam ships and railroads. 
FIGURE 2

MAP OF RAILROADS IN PERU, 1930

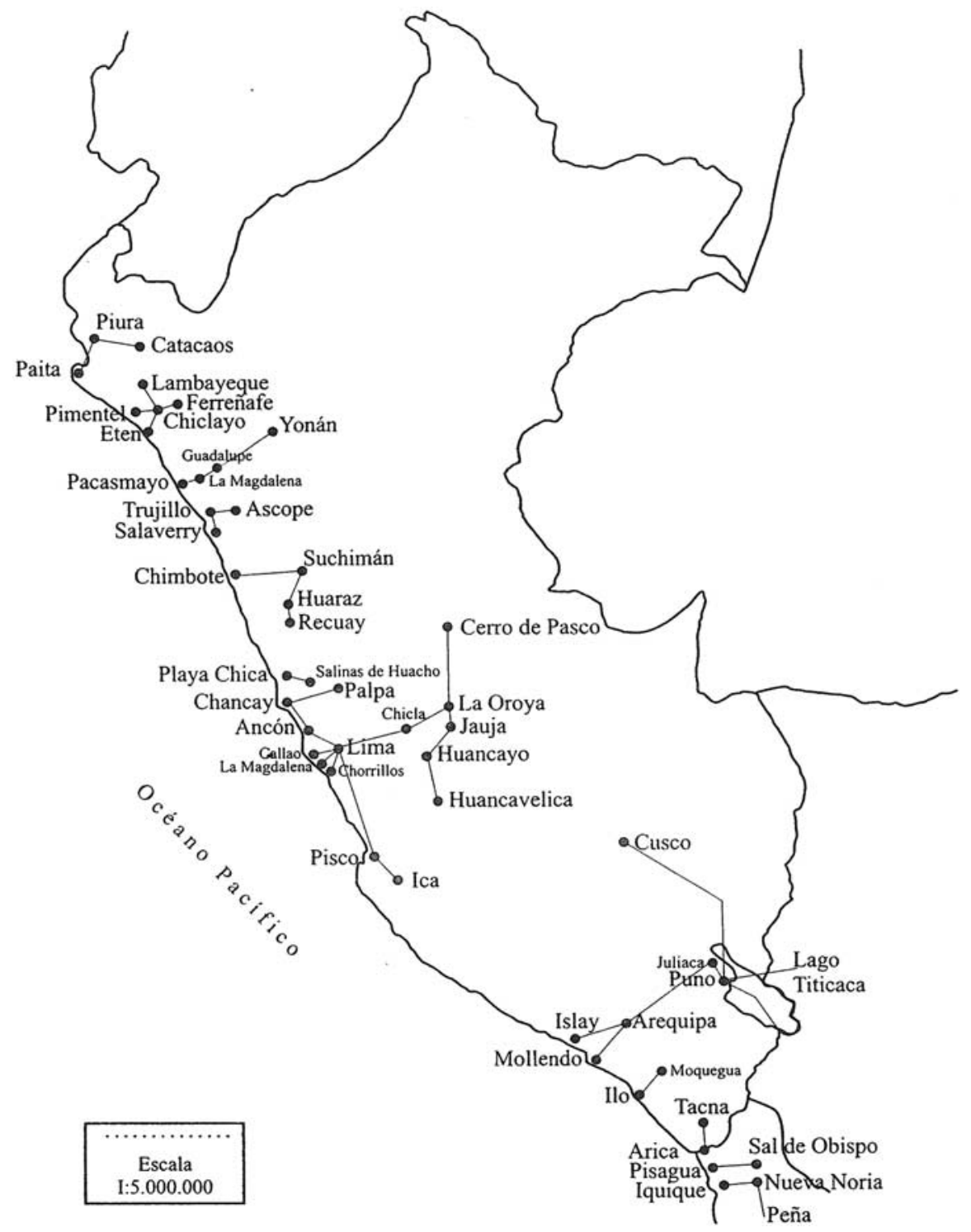

Source: Deustua (2010, p. 191). 
Let us start with the analysis of the traditional system of animal transportation. Table 1 reports freight rates for using mules and llamas. There was great disparity in freight rates between different routes, regions and dates. However, it is possible to locate some patterns that will allow us to identify some of the determinants of freight rates.

First of all, some of the differences in freight rates were due to the differences in the demand for mules and llamas. The importance of demand seems high when looking at the evolution of freight rates. As the need for transportation increased, freight rates increased. According to Miller (1976), for example, as the production of copper started to boom in the central highlands in the late 1890s, the demand for transporting copper, therefore, increased and the price of transportation increased substantially. The cost of renting a mule (in constant 1,900 soles per tonne) for the Cerro de Pasco-La Oroya route increased from 21 soles in 1896 to 104 soles in 1898, although it then declined to 70 soles in 1900. Over the same period, the cost of renting a llama rose fourfold (Miller 1976). Freight rates were high in 1900 not only for Cerro-La Oroya but also for other mining routes, such as Cerro de Pasco-Goyllarisquizga and Cerro de Pasco-Yanahuanca. Contreras (2004) indicates that some attempts to reduce transport costs were made, but they were not successful. In 1899, a transportation company and miners reached an agreement to charge 53 current soles for transporting minerals from Cerro de Pasco to La Oroya. The company hired arrieros and provided the service to miners. However, this agreement was soon broken because of the scarcity of men. The company did not find arrieros to transport the mineral, requesting miners to bring their own men. Arrieros' salaries and the consequent cost of transportation then increased.

In other regions, freight rates also increased in response to the increasing demand for transportation. The increase in coffee production in Junin, for example, led to an increase in the price of transportation. According to the municipality of Chanchamayo, freight rates by mule between La Oroya and La Merced increased from 30 constant soles in 1894 to 52 constant soles in 1895 (Pinto and Salinas 2009, p. 130).

On the other hand, the construction of railroads increased the supply of transportation and led to a reduction in freight rates. For instance, on the La Oroya-Huancayo route mule freight rates declined from 80 constant soles in 1900 to only 28 constant soles in 1906. Furthermore, with the construction of railroads, the demand for mules and llamas declined in nearby regions, and thus the cost of renting these animals declined.

In addition, rates depended on the difficulty of the journey. In particular, the price of transportation was greater on uphill routes than on downhill journeys, because the depreciation of the animal was greater in the case of the former. For the Huarochiri-Chicla route, for example, Deustua (2009) indicates that in the late 1880 s the price of transportation by mule was 19.8 constant soles on uphill routes and 17.8 soles per tonne downhill, whereas the corresponding freight rates by llama were 5.9 soles and 4.5 soles per tonne. 


\begin{tabular}{|c|c|c|c|c|c|c|}
\hline \multicolumn{7}{|r|}{ TION } \\
\hline \multirow[b]{2}{*}{ Route } & \multirow[b]{2}{*}{ Region $^{1}$} & \multirow[b]{2}{*}{ Year } & \multirow[b]{2}{*}{$\begin{array}{c}\text { Distance } \\
\text { (miles) }\end{array}$} & \multicolumn{2}{|c|}{1,900 soles } & \multirow[b]{2}{*}{ Source } \\
\hline & & & & $\begin{array}{c}\text { Cost per } \\
\text { tonne }\end{array}$ & $\begin{array}{c}\text { Cost per } \\
\text { tonne-mile }\end{array}$ & \\
\hline \multicolumn{7}{|l|}{ Mule transportation/1830-1870 } \\
\hline Cerro de Pasco-Lima & $\mathrm{C} / \mathrm{H}$ & 1836 & 204 & 57.2 & 0.28 & Deustua (2009) \\
\hline Lima-Callao & $\mathrm{C}$ & 1860 & 9 & 3.8 & 0.44 & McEvoy (2004) \\
\hline Jauja-Lima & $\mathrm{C} / \mathrm{H}$ & 1860 & 156 & 63.3 & 0.41 & McEvoy (2004) \\
\hline Islay-Arequipa & $\mathrm{C}$ & 1856 & 104 & 32.0 & 0.31 & Bonilla (1976) \\
\hline Islay-Arequipa & $\mathrm{C}$ & 1862 & 104 & 38.3 & 0.37 & Bonilla (1976) \\
\hline Arequipa-Puno & $\mathrm{H}$ & $1860 \mathrm{~s}$ & 184 & 35.1 & 0.19 & Flores (1993) \\
\hline Arequipa-Cuzco & $\mathrm{H}$ & $1860 \mathrm{~s}$ & 415 & 105.4 & 0.25 & Flores (1993) \\
\hline \multicolumn{7}{|l|}{ Mule transportation/1880-1920 } \\
\hline Highlands $^{2}$ & $\mathrm{H}$ & 1909 & & & 0.42 & Tizón (1909) \\
\hline Cerro de Pasco-Callao & $\mathrm{C} / \mathrm{H}$ & 1890 & 196 & 178.6 & 0.91 & Miller (1976) \\
\hline Cerro de Pasco-La Oroya & $\mathrm{H}$ & 1896 & 83 & 21.1 & 0.25 & Miller (1976) \\
\hline Cerro de Pasco-La Oroya & $\mathrm{H}$ & 1898 & 83 & 104.0 & 1.25 & Miller (1976) \\
\hline Cerro de Pasco-La Oroya & $\mathrm{H}$ & 1900 & 83 & 70.0 & 0.84 & Miller (1976) \\
\hline Cerro de Pasco-Casapalca & $\mathrm{H}$ & 1897 & 112 & 37.1 & 0.33 & Miller (1976) \\
\hline Cerro de Pasco-Goyllarisquizga & $\mathrm{H}$ & 1900 & 22 & 33.0 & 1.48 & Miller (1976) \\
\hline Cerro de Pasco-Yanahuanca & $\mathrm{H}$ & 1900 & 29 & 24.0 & 0.84 & Miller (1976) \\
\hline La Merced-Tarma & $\mathrm{H}$ & 1886 & 48 & 52.3 & 1.09 & Pinto and Salinas (2009) \\
\hline La Merced-La Oroya & $\mathrm{H} / \mathrm{J}$ & 1894 & 79 & 29.7 & 0.38 & Pinto and Salinas (2009) \\
\hline La Merced-La Oroya & $\mathrm{H} / \mathrm{J}$ & 1895 & 79 & 51.5 & 0.65 & Pinto and Salinas (2009) \\
\hline Huarochiri-Chicla (down) & $\mathrm{H}$ & 1889 & 19 & 17.8 & 0.96 & Deustua (2009) \\
\hline
\end{tabular}


TABLE 1 (Cont.)

\begin{tabular}{|c|c|c|c|c|c|c|}
\hline \multirow[b]{2}{*}{ Route } & \multirow[b]{2}{*}{ Region $^{1}$} & \multirow[b]{2}{*}{ Year } & \multirow[b]{2}{*}{$\begin{array}{c}\text { Distance } \\
\text { (miles) }\end{array}$} & \multicolumn{2}{|c|}{1,900 soles } & \multirow[b]{2}{*}{ Source } \\
\hline & & & & $\begin{array}{c}\text { Cost per } \\
\text { tonne }\end{array}$ & $\begin{array}{l}\text { Cost per } \\
\text { tonne-mile }\end{array}$ & \\
\hline Huarochiri-Chicla (up) & $\mathrm{H}$ & 1889 & 19 & 19.8 & 1.06 & Deustua (2009) \\
\hline La Oroya-Huancayo & $\mathrm{H}$ & 1900 & 96 & 80.0 & 0.84 & Miller (1976) \\
\hline La Oroya-Huancayo* & $\mathrm{H}$ & 1906 & 96 & 28.0 & 0.29 & Miller (1976) \\
\hline La Oroya-Perene & $\mathrm{H}$ & 1901 & 99 & 74.3 & 0.75 & Miller (1976) \\
\hline La Oroya-Jauja* & $\mathrm{H}$ & 1906 & 71 & 20.3 & 0.28 & Miller (1976) \\
\hline Jauja-Tarma & $\mathrm{H}$ & 1906 & 36 & 12.7 & 0.35 & Miller (1976) \\
\hline Huancayo-Jauja & $\mathrm{H}$ & 1906 & 24 & 11.0 & 0.45 & Miller (1976) \\
\hline Huancayo-Chanchamayo & $\mathrm{H}$ & 1906 & 99 & 50.9 & 0.51 & Miller (1976) \\
\hline Huancayo-Huancavelica & $\mathrm{H}$ & 1906 & 68 & 41.5 & 0.61 & Miller (1976) \\
\hline Huancayo-Ayacucho & $\mathrm{H}$ & 1906 & 160 & 92.4 & 0.58 & Miller (1976) \\
\hline Ayacucho-Pisco & $\mathrm{C} / \mathrm{H}$ & 1909 & 186 & 108.2 & 0.58 & Tizón (1909) \\
\hline \multicolumn{7}{|l|}{ Llama transportation } \\
\hline Huarochiri-Chicla (down) & $\mathrm{H}$ & 1889 & 19 & 4.5 & 0.24 & Deustua (2009) \\
\hline Huarochiri-Chicla (up) & $\mathrm{H}$ & 1889 & 19 & 5.9 & 0.32 & Deustua (2009) \\
\hline Parac-Chicla & $\mathrm{H}$ & 1893 & 17 & 4.7 & 0.27 & Deustua (2009) \\
\hline Parac-San Mateo & $\mathrm{H}$ & 1893 & 10 & 4.7 & 0.45 & Deustua (2009) \\
\hline Elisa (mine)-Casapalca & $\mathrm{H}$ & 1892 & 5 & 2.8 & 0.57 & Deustua (2009) \\
\hline Highlands $^{2}$ & $\mathrm{H}$ & 1909 & 173 & 36.1 & 0.21 & Tizón (1909) \\
\hline
\end{tabular}

Notes: Freight rates are in 1,900 soles.

${ }^{1} \mathrm{C}$ : coast, H: highlands, J: jungle.

${ }^{2}$ Tizón (1909) reports freight-rate figures for a distance of 50 leagues in the highlands for mules and llamas. Tizón does not specify a route.

*A railway competed with mule transport for the whole of part of the route. 
Finally, llama freight rates were usually cheaper than mule rates. Llama rates were usually lower than 0.5 soles per tonne-mile, whereas mule rates were usually higher than 0.5 soles per tonne-mile, and in some cases they were more than 1 sol per tonne-mile ${ }^{20}$. The lower cost of using llamas is not surprising considering that these animals did not require much care, since they mostly fed upon practically all species of herbage from the mountains, and were better suited than mules to the natural conditions of the Andes (Hills 1860, p. 101). In addition, by the mid- $19^{\text {th }}$ century, the price of a strong, fully grown llama ranged between 3 and 4 soles, and a regular llama could be purchased for 2 soles (Tschudi 1847, p. 308); however, the price of a regular mule ranged between 45 and 50 soles, and could reach up to 250 soles (Deustua 2009, pp. 176-177).

A comparison with other modes of transportation indicates that the traditional system of animal transportation was very costly, especially as the needs for transportation increased at the turn of the century. Let us consider the freight rates charged by railroads, a more time efficient mode of transportation. Table 2 reports the effective freight rates for a number of routes for three types of freight ${ }^{21}$. First class referred to imported goods, second class to manufacturing goods and third class to mining and agricultural products.

If we compare mule and railroad rates, we find that effective freight rates were usually lower for railroads than for mules, especially on long routes. According to Tizón (1909), transporting loads by mule cost around 0.42 soles per tonne-mile in the highlands. This rate was higher than third-class effective freight rates for most railroads, and was higher than second-class rates for railroad journeys of more than 10 miles. Since mineral and agricultural products were transported in third-class wagons, transporting these products by railroad was cheaper than transporting by mule. Other estimates indicate higher freight rates for mules. The cost of renting a mule for carrying freight was around 1 sol by 1900 on the La Oroya-Cerro de Pasco route. This rate was higher than railroad rates in the Central Railway on the Callao-La Oroya-Cerro de Pasco route, even in first class.

Consider the composition of production costs of copper, including extraction, concentration and transportation from Cerro de Pasco to Europe ${ }^{22}$. Transportation by animals from Cerro de Pasco to La Oroya accounted for 35 per cent of total cost, whereas transportation from La Oroya to Callao accounted for 11 per cent ${ }^{23}$. Animal transportation was then much more costly than railroad transportation. The cost of transporting copper from Cerro de

20 Tizón (1909) indicated that llama rates in the highlands were half mule rates.

21 Effective freight rates include terminal fees.

22 In 1900, the total cost of transporting copper from Cerro de Pasco to La Oroya by mule and llama was 836,000 current soles, and the cost of transporting the same mineral from La Oroya to Callao by the Central Railway was only 262,000 current soles. This information is reported by Garland (1901).

${ }^{23}$ Extraction and concentration represented only 6 per cent of total cost. 
TABLE 2

RAILROADS OF PERU: FREIGHT RATES PER METRIC TONNE (1,900 SOLES), 1908

\begin{tabular}{|l|c|c|c|c|c|c|c|}
\hline & & \multicolumn{2}{|c|}{ First class $^{\mathbf{a}}$} & \multicolumn{2}{c|}{ Second class } & \multicolumn{2}{|c|}{ Third class } \\
\cline { 3 - 8 } Railroad & $\begin{array}{c}\text { Distance } \\
\text { (miles) }\end{array}$ & $\begin{array}{c}\text { (soles } \\
\text { per } \\
\text { tonne) }\end{array}$ & $\begin{array}{c}\text { (soles } \\
\text { per } \\
\text { tonne- } \\
\text { mile) }\end{array}$ & $\begin{array}{c}\text { (soles } \\
\text { per } \\
\text { tonne) }\end{array}$ & $\begin{array}{c}\text { poles } \\
\text { tonne- } \\
\text { mile) }\end{array}$ & $\begin{array}{c}\text { (soles } \\
\text { per } \\
\text { tonne) }\end{array}$ & $\begin{array}{c}\text { per } \\
\text { tonne- } \\
\text { mile) }\end{array}$ \\
\hline Paita-Piura & 60 & 12.28 & 0.20 & 9.83 & 0.16 & 8.18 & 0.14 \\
\hline Eten-Chiclayo-Patapo & 31 & 11.70 & 0.38 & 10.03 & 0.32 & 8.36 & 0.27 \\
\hline Pacasmayo-Guadalupe & 26 & 10.59 & 0.41 & 9.05 & 0.35 & 7.50 & 0.29 \\
\hline Pacasmayo-Yonan & 40 & 13.96 & 0.35 & 12.04 & 0.30 & 10.12 & 0.25 \\
\hline Salaverry-Trujillo-Ascope & 47 & 15.62 & 0.33 & 13.52 & 0.29 & 10.14 & 0.21 \\
\hline Chimbote-Tablones & 35 & 12.75 & 0.36 & 10.95 & 0.31 & 9.20 & 0.26 \\
\hline Supe-Tambo Viejo & 7 & 5.96 & 0.80 & 4.93 & 0.66 & 3.90 & 0.52 \\
\hline Lima-Callao & 9 & 7.84 & 0.92 & 0.00 & 0.00 & 0.00 & 0.00 \\
\hline Lima-Chorrillos & 9 & 8.34 & 0.96 & 0.00 & 0.00 & 0.00 & 0.00 \\
\hline Callao-La Oroya & 138 & 33.76 & 0.24 & 29.24 & 0.21 & 24.80 & 0.18 \\
\hline Lima-Ancon & 24 & 8.68 & 0.37 & 7.26 & 0.31 & 5.84 & 0.25 \\
\hline Callao-La Oroya-Cerro de & 220 & 55.90 & 0.25 & 49.16 & 0.22 & 41.41 & 0.19 \\
\hline Pasco & & & & & & & 0.19 \\
\hline Callao-Ticlio-Morococha & 115 & 40.66 & 0.35 & 35.25 & 0.31 & 29.99 & 0.26 \\
\hline Tambo de Mora-Chincha & 7 & 5.35 & 0.72 & 4.32 & 0.58 & 3.29 & 0.44 \\
\hline Mollendo-Arequipa & 107 & 20.92 & 0.20 & 17.58 & 0.16 & 13.39 & 0.13 \\
\hline Mollendo-Puno & 325 & 56.15 & 0.17 & 46.93 & 0.14 & 36.88 & 0.11 \\
\hline Mollendo-Sicuani & 419 & 71.41 & 0.17 & 59.51 & 0.14 & 47.02 & 0.11 \\
\hline Mollendo-Ensenada- & 18 & 0.00 & 0.00 & 0.00 & 0.00 & 0.00 & 0.00 \\
\hline Pampa Blanca & & & & & & & \\
\hline
\end{tabular}

Notes and sources: The sources are Costa y Laurent (1908) and Galessio (2007).

Data are not available for Lima-Magdalena and for Pisco-Ica.

${ }^{a}$ In the cases of Lima-Callao and Lima-Chorrillos (1908), freight rates are the only rates available.

Pasco to La Oroya was around three times the cost of transporting the same amount of mineral from La Oroya to Callao, even though the distance was much shorter: the distance between Cerro de Pasco and La Oroya was 82 miles, whereas the distance between La Oroya and Callao was almost 140 miles.

On the other hand, traditionally, the transportation of light loads for short distances was conducted on the backs of llamas. Compared to railroads, 
llamas were much slower, but were not necessarily cheaper, especially as the demand for transportation increased. Tizón (1909) indicates that llama rates were around 0.21 constant soles per tonne-mile in 1900 prices. For the $1890 \mathrm{~s}$, Deustua (2009) indicates that llameros charged even more than 0.40 soles per tonne-mile. Third-class freight rates by railroad were not necessarily higher than llama rates. For example, the freight rate for third class by railroad on the Callao-Cerro de Pasco route was 0.19 soles per tonne-mile, whereas the freight rate between Callao and Morococha was 0.26 soles per tonne-mile ${ }^{24}$.

Motivated by the high transport costs of the traditional system of mules (in time costs and freight rates) and llamas (especially in time costs), several miners supported the construction of the Central Railway. As Contreras (2004) argues, once the railroad reached La Oroya, there were several attempts to extend the line to Cerro de Pasco. Backus y Johnston and Ernest Thorndike obtained permission to conclude the railroad to Cerro de Pasco. On the northern coast, sugar and cotton hacendados also supported and funded the construction of railroads.

The railroad led to a decline in freight rates. Nevertheless, the reduction in freight rates due to the railroad in Peru was much lower than in other Latin American countries. On average, the rail freight rate in Peru was around 0.16 soles per tonne-mile in 1900 prices. On the basis of the sample of freight rates reported in Table 1, mule freight rates were on average around 2.5 times the average rail freight rate and were always lower than five times the average freight rate, whereas the rate in the case of llamas was less than twice the average rail rate ${ }^{25}$. These differences in freight rates in Peru between railroads and the alternative system of overland transportation were not as large as in Mexico and Brazil. In these two countries, wagons were the best alternative mode of transportation. In Brazil, wagons charged between 7.5 and 14.3 times the average rail freight rate; in Mexico, wagons charged between 5.1 and 10.5 times the average rail rate. The construction of railroads in Peru, then, reduced freight rates, but not to the same extent as it did in Mexico and Brazil ${ }^{26}$.

${ }^{24}$ According to Miller (1976), around one-third of mining production from Cerro de Pasco was taken to Callao by llama in 1890, even though it was possible to take it by railroad. This reference has been taken from Deustua (2009). The lower cost for using llamas is not surprising considering that llamas did not require much care, since they mostly fed upon practically all species of herbage from the mountains and were better suited than mules to the natural conditions of the Andes (Hills 1860, p. 101).

${ }_{25}$ These figures were calculated using the freight rates reported by Coatsworth (1979) and Summerhill (2005). These differences in rates may have implied private gains for some firms that were served by the railroad and therefore paid less for transportation.

${ }^{26}$ One possible explanation for the lower reduction in freight rates due to the railroad was the ruggedness of the Peruvian landscape, which led to high operating costs and high rail freight rates; compare, for example, Peru and Brazil. On average, the rail freight rate was U.S. $\$ 0.09$ per tonnemile in Peru, almost twice as much as in Brazil. The evidence suggests that these differences in freight rates were due to differences in operating costs. In fact, the gross revenues/operating costs ratio was the same in Peru and Brazil: the ratio was 1.54 in both countries (1,904 for Peru and 1,913 
TABLE 3

OCEAN FREIGHT RATES, 1876

\begin{tabular}{|l|c|c|c|}
\hline & \multirow{2}{*}{ Distance (miles) } & \multicolumn{2}{|c|}{ Freight rate (1900 prices) } \\
\cline { 3 - 4 } & 793 & (soles per tonne) & (soles per tonne-mile) \\
\hline Callao-Puerto Pizarro & 626 & 9.67 & 0.0122 \\
\hline Callao-Paita & 135 & 9.02 & 0.0144 \\
\hline Callao-Tambo de Mora & 326 & 11.62 & 0.0670 \\
\hline Callao-Chala & 518 & 12.92 & 0.0357 \\
\hline Callao-Quilca & 548 & 12.92 & 0.0250 \\
\hline Callao-Islay & 618 & 12.92 & 0.0236 \\
\hline Callao-Ilo & 711 & 12.92 & 0.0209 \\
\hline Callao-Arica & & & 0.0182 \\
\hline
\end{tabular}

Sources: Lemale (1876), Briceño y Salinas (1927) and Bonilla (1976).

Considering the lack of railroads, the sea was an important means of communication between coastal towns. Table 3 reports data on steam freight rates for 1876 in 1,900 soles. Total transportation cost included shipping rates and port fees ${ }^{27}$. Freight rates ranged between 0.01 and 0.09 constant soles per tonne-mile. The figures suggest the presence of scale economies on distance to a large extent for the high cost of using ports: freight rates were lower for longer distances. The distance between the ports of Callao and Tambo de Mora, for example, was only 135 miles and the freight rate was above 0.08 constant soles per tonne-mile. In contrast, the distance between the ports of Callao and Puerto Pizarro was 793 miles and the freight rate was 0.016 constant soles per tonne-mile. Similarly, the distance between the ports of Callao and Arica was 711 miles and the freight rate was less than 0.03 constant soles per tonne-mile. These figures indicate that the sea as a means of transportation was far cheaper than mules or llamas, especially for long distances ${ }^{28}$. The sea, however, could not replace

\section{(F'note continued)}

for Brazil). The higher rail freight rates in Peru seem to be caused by higher operating costs, rather than a higher profit margin.

27 Steam freight rates refer to the Pacific Steam Navigation Co. Port fees in Callao, which were significant, were included in the freight rates. A British council in Islay indicated in 1862 that the total port cost was more than 8 pesos per tonne for using this port. This cost is added to shipping freight rates to estimate the total cost of transportation.

28 According to Deustua (2009), for example, the merchant Patrico Ginez used mules and horses to transport goods along the coast; but his favoured means of transportation was the sea (Deustua 2009, p. 177). 
animal transportation as it faced a natural limitation: it could only be used for transporting goods along the coast.

This survey of freight rates shows that the price of transportation for using mules was greater than the price for using the railroad and steam navigation, especially as the needs for transportation increased from the late 1890s. Muleteering was not only a time-inefficient mode of transportation; it was also relatively expensive. Llamas provided a cheaper system of transportation than mules but were much slower than railroads and steam ships and carried much less than mules. However, railroads were limited and did not reach most of the Peruvian territory, and rivers in coastal and highland regions were not navigable, and thus mules and llamas constituted the only or the predominant mode of transportation. Finally, although railroads provided a cheaper mode of transportation than mules and llamas, the reduction in freight rates was not as large as in other Latin American countries.

\section{SPEED AND TIME COSTS}

Time was a valuable asset. The slow transportation of freight reduced the movement of capital and probably reduced investment opportunities. Thus, low-speed modes of transportation may have reduced the incentives to trade, the gains from specialisation and economic growth.

Table 4 reports the average speed of freight transportation for several routes. The speed of mules in transporting freight was not always the same, since it depended on the conditions of the road and the topography of the terrain. In 1906, Cisneros indicated that a loaded mule could complete up to 4 miles per hour, or 34 miles per day, on a regular road in the highlands. Other sources indicate lower speeds. According to McGregor, mules usually took between 9 and 10 days to complete the Lima-Cerro de Pasco route at an average of 19 miles per day. According to Vega and Sulca (2005), herds of mules usually took 9 days to complete the Huamanga-Abancay route in the southern highlands at an average speed of 20 miles per day, and took 7 days to complete the Abancay-Cuzco route at a speed of 16 miles per day.

Llamas were slower than mules. Tschudi (1847) indicates that llamas were able to cover between 3 and 4 leagues per day, that is, around 12 miles per day. Similarly, Hills (1860) indicates that llamas rarely managed more than 12 or 13 miles per day. For Cisneros (1906), llamas could complete up to 16 miles per day. Since llamas were never fed during the night, the llamero had to stop during the journey to allow the animals to graze (Tschudi 1847, p. 308).

Railroads constituted an alternative mode of transportation from the mid$19^{\text {th }}$ century. Table 5 reports the speed of railroads for a number of routes in 1908. Trains were faster than 7 miles per hour, and thus railroads represented a much faster mode of transportation than mules and llamas. In the central region, for example, a train only took 11 hours to complete the route 
TABLE 4

DURATION OF TRIPS AND SPEED OF TRADITIONAL OVERLAND TRANSPORTATION

\begin{tabular}{|c|c|c|c|c|c|c|}
\hline Route & Main region & Year & $\begin{array}{c}\text { Distance } \\
\text { (miles) }\end{array}$ & $\begin{array}{l}\text { Time } \\
\text { (days) }\end{array}$ & $\begin{array}{l}\text { Speed } \\
\text { (miles/ } \\
\text { day) }\end{array}$ & Source \\
\hline \multicolumn{7}{|l|}{$\begin{array}{l}\text { Freight transportation } \\
\text { by mules }\end{array}$} \\
\hline Highlands & $\mathrm{H}$ & $1900 \mathrm{~s}$ & & & 34.2 & $\begin{array}{c}\text { Cisneros } \\
(1906)\end{array}$ \\
\hline Lima-Cerro de Pasco & H-Centre & $1890 \mathrm{~s}$ & 204.3 & 9.5 & 21.5 & $\begin{array}{r}\text { Bonilla } \\
(1976)\end{array}$ \\
\hline Tarma-La Merced & $\mathrm{H} / \mathrm{J}-$ Centre & 1886 & 47.8 & 5.0 & 9.6 & $\begin{array}{l}\text { Pinto } \\
\text { and } \\
\text { Salinas } \\
(2009)\end{array}$ \\
\hline Islay-Arequipa & $\mathrm{C} / \mathrm{H}$-Centre & 1856 & 103.9 & 2.5 & 41.5 & $\begin{array}{r}\text { Bonilla } \\
(1976)\end{array}$ \\
\hline Arequipa-Cuzco & H-South & $1860 \mathrm{~s}$ & 415.5 & 10.0 & 41.5 & $\begin{array}{l}\text { Flores } \\
(1993)\end{array}$ \\
\hline Arequipa-Puno & H-South & $1860 \mathrm{~s}$ & 183.5 & 6.0 & 30.6 & $\begin{array}{l}\text { Flores } \\
(1993)\end{array}$ \\
\hline Huamanga-Abancay & H-South & $\begin{array}{l}\text { 19th } \\
\text { century }\end{array}$ & 180.0 & 9.0 & 20.0 & $\begin{array}{c}\text { Vega and } \\
\text { Julca } \\
(2005)\end{array}$ \\
\hline Abancay-Cuzco & H-South & $\begin{array}{l}\text { 19th } \\
\text { century }\end{array}$ & 110.8 & 7.0 & 15.8 & $\begin{array}{c}\text { Vega and } \\
\text { Julca } \\
(2005)\end{array}$ \\
\hline \multicolumn{7}{|l|}{$\begin{array}{l}\text { Freight transportation } \\
\text { by llamas }\end{array}$} \\
\hline Highlands & $\mathrm{H}$ & $1840 \mathrm{~s}$ & & & 12.1 & $\begin{array}{r}\text { Tschudi } \\
\text { (1847) }\end{array}$ \\
\hline Highlands & $\mathrm{H}$ & $1850 \mathrm{~s}$ & & & 12.5 & $\begin{array}{l}\text { Hills } \\
(1860)\end{array}$ \\
\hline Highlands & $\mathrm{H}$ & $1900 \mathrm{~s}$ & & & 15.5 & $\begin{array}{c}\text { Cisneros } \\
\quad(1906)\end{array}$ \\
\hline
\end{tabular}

Notes: $\mathrm{C}=$ coast $; \mathrm{H}=$ highlands; $\mathrm{J}=$ jungle.

Lima-Cerro de Pasco, traversing the Andes Mountains, whereas transportation by mule and llama took longer. In 1847, the British Council's John McGregor indicated that animals usually took a rest in Obrajillo on the Lima-Cerro de Pasco route, before continuing the difficult journey up into the mountains; the Lima-Cerro de Pasco route could then take 9 or 10 days 
TABLE 5

DURATION OF TRIPS AND SPEED OF RAILROADS

\begin{tabular}{|c|c|c|c|c|}
\hline Route & $\begin{array}{c}\text { Distance } \\
\text { (miles) }\end{array}$ & $\begin{array}{c}\text { Time } \\
\text { (hours) }\end{array}$ & $\begin{array}{c}\text { Speed } \\
\text { (m.p.h.) }\end{array}$ & Region \\
\hline \multicolumn{5}{|l|}{ North } \\
\hline Piura-Catacaos & 7 & $00: 30$ & 13.2 & Coast \\
\hline Pimentel-Chiclayo & 9 & $00: 45$ & 11.6 & Coast \\
\hline Eten-Chiclayo-Patapo & 26 & 03:45 & 7.0 & Coast \\
\hline Pacasmayo-Guadalupe & 26 & 02:45 & 9.5 & Coast \\
\hline Pacasmayo-Yonan & 40 & 05:00 & 8.1 & Coast \\
\hline Salaverry-Trujillo-Ascope & 47 & 03:55 & 12.1 & Coast \\
\hline \multicolumn{5}{|l|}{ Center } \\
\hline Chimbote-Tablones & 35 & 03:40 & 9.7 & Coast \\
\hline $\begin{array}{l}\text { Supe-Barranca-Tambo } \\
\text { Viejo }\end{array}$ & 7 & 00:50 & 8.9 & Coast \\
\hline Lima-Ancon & 24 & 02:00 & 11.9 & Coast \\
\hline Lima-Callao & 9 & $00: 28$ & 18.3 & Coast \\
\hline Lima-Chorrillos & 9 & $00: 28$ & 18.7 & Coast \\
\hline Callao-La Oroya & 138 & $11: 45$ & 11.7 & Coast/Highlands \\
\hline La Oroya-Cerro de Pasco & 82 & $06: 25$ & 12.8 & Highlands \\
\hline \multicolumn{5}{|l|}{ South } \\
\hline Pisco-Ica & 46 & 03:40 & 12.5 & Coast \\
\hline Tambo de Mora-Chincha & 7 & $00: 32$ & 13.9 & Coast \\
\hline Arequipa-Mollendo & 107 & $06: 45$ & 15.8 & Coast \\
\hline Arequipa-Puno & 218 & $12: 25$ & 17.6 & Highlands \\
\hline Juliaca-Sicuani & 123 & 09:30 & 12.9 & Highlands \\
\hline
\end{tabular}

Source: Costa y Laurent (1908).

for muleteers. Deustua (2009) indicates that the railroad took 1 day to transport minerals from Callao to Chicla, whereas herds of mules took 7 or 8 days. In the south, the Pisco-Ica railroad completed the 48-mile route in less than 4 hours. In contrast, travellers could take nearly a day by horse through the desert. On his 1838-1842 trips, J. J. Tschudi completed the journey from Pisco to Ica in 1 day. The journeys were undertaken by horse and through the desert from $3 \mathrm{pm}$ to the next morning, avoiding the noon heat ${ }^{29}$.

29 The Mollendo-Arequipa-Puno railroad was also much faster than traditional travel methods. The speed of trains on this railroad was above 15 miles per hour. In contrast, in the 1850s S. S. Hills 
Therefore, the transportation system of mules and llamas was very slow in comparison to the railway system. Since most of Peru did not have railroads, transportation in most regions was relatively slow. Precisely, Dávalos y Lissón (1919) indicated that since Peru had not «improved the scarce, narrow and dangerous roads ... the social and political life of the nation is more or less similar to that in the Colony. Towns are isolated some from the others. It is not easy for their inhabitants to travel and they never know the rest of the nation where they live... The people who are hired from the highlands to work for a salary in the haciendas of Pativilca, Casma, Chimbote, Chicama, etc, travel on foot such as during Inca times, needing from four to six days to walk distances of no more than 24 to 28 leagues, which would only require eight or ten hours if traveled by railroad or by car» (Dávalos y Lissón 1919, p. 371).

Considering the slow construction of railroads and the difficulties of traditional overland transportation, the sea was an alternative means of transportation for coastal towns (Table 6). A comparison of navigation and animal transportation indicates that sailing ships were more time-efficient than animals when following the Humboldt Current, but yielded about the same time costs when navigating against the current. The speed of mules was around 30 miles a day, whereas that of sailing ships was usually greater than 80 miles a day when navigating northward. Steam ships were much faster than animals with speeds of above 200 miles a day, and in many cases exceeding 270 miles a day. For instance, a steam ship departing from Callao and arriving in Huanchaco completed 298 miles per day. Steam ships, therefore, were much more time-efficient than mules and llamas.

In conclusion, the transportation system of mules and llamas was much slower than railroads and steam ships. Since most routes were completed by the traditional system of animal transportation (only a few railroads had been built and the sea could only be used to connect coastal towns, where only a small proportion of the population lived), the system of transportation of Peru generated high time costs.

\section{TRANSPORT COSTS AND ECONOMIC GROWTH}

Transportation in most of Peru was conducted by the traditional system of mules and llamas. Waterways and railroads only served a small portion of the territory. Transportation costs were high, which probably constituted a barrier to trade and hindered economic growth. As transport costs were high,

\footnotetext{
(F'note continued)

travelled from the port of Islay to the city of Arequipa at an average speed of 48 miles per day, from Arequipa to Cuzco at an average speed of 46 miles per day, and from Cuzco to Puno at an average speed of 29 miles per day.
} 
TABLE 6

TIME COSTS AND SPEED OF SAILING AND STEAM SHIPS

\begin{tabular}{|c|c|c|c|c|c|}
\hline & \multirow[b]{2}{*}{$\begin{array}{c}\text { Distance } \\
\text { (miles) }\end{array}$} & \multicolumn{2}{|c|}{ Time duration } & \multicolumn{2}{|c|}{$\begin{array}{c}\text { Speed } \\
\text { (miles per day) }\end{array}$} \\
\hline & & $\begin{array}{l}\text { Sailing } \\
\text { ships }\end{array}$ & $\begin{array}{l}\text { Steam } \\
\text { ships }\end{array}$ & $\begin{array}{l}\text { Sailing } \\
\text { ships }\end{array}$ & $\begin{array}{l}\text { Steam } \\
\text { ships }\end{array}$ \\
\hline \multicolumn{6}{|l|}{ North to South } \\
\hline Paita-Callao & 626 & 15 days & $\begin{array}{l}2 \text { days } \\
7 \text { hours }\end{array}$ & 41.7 & 273.2 \\
\hline Huanchaco-Callao & 336 & 7 days & $\begin{array}{c}1 \text { day } \\
12 \text { hours }\end{array}$ & 48.0 & 224.0 \\
\hline Callao-Islay & 548 & 18 days & 2 days & 30.4 & 273.9 \\
\hline Callao-Arica & 711 & 18 days & 3 days & 39.5 & 237.1 \\
\hline Callao-Iquique & 838 & 18 days & $\begin{array}{l}3 \text { days } \\
12 \text { hours }\end{array}$ & 46.5 & 239.4 \\
\hline \multicolumn{6}{|l|}{ South to North } \\
\hline Callao-Paita & 626 & 6 days & $\begin{array}{l}2 \text { days } \\
5 \text { hours }\end{array}$ & 104.3 & 283.5 \\
\hline Callao-Huanchaco & 336 & 4 days & $\begin{array}{c}1 \text { day } \\
3 \text { hours }\end{array}$ & 84.0 & 298.7 \\
\hline Islay-Callao & 548 & $\begin{array}{l}4 \text { days } \\
12 \text { hours }\end{array}$ & $\begin{array}{l}1 \text { day } \\
18 \text { hours }\end{array}$ & 121.7 & 313.0 \\
\hline Arica-Callao & 711 & 6 days & $\begin{array}{l}2 \text { days } \\
12 \text { hours }\end{array}$ & 118.5 & 284.5 \\
\hline Iquique-Callao & 838 & 7 days & 3 days & 119.7 & 279.3 \\
\hline
\end{tabular}

Source: Denegri (1976) and Espinosa (2002).

many towns probably had limitations to participate in trade with other towns, and thus each town produced what it needed to live. In these circumstances, Peru may have faced severe obstacles to exploit its vast natural resources. Dávalos y Lissón (1919), for example, argues that

«... most mining companies located in Pallasca, Huailas, Cajabamba, Hualgayoc, Cajatambo, Huallanca and some others had experienced an anemic life because of the lack of means of communication. There is nothing richer in Peru in silver, lead, carbon and tungsten than Ancash, or nothing more abundant in gold than Pataz; but since we do not even have horseshoe roads in those provinces, every effort is exhausted for the impossibility of transportation. For the same cause, the great agricultural wealth of Jaen and Maynas has no value. 
Not even at ten soles per acre can land be sold, not existing roads to reach them....» Dávalos y Lissón (1919, p. 373).

The natural limitations of using animals to transport heavy goods constituted a particular constraint to investment and economic growth. Mules could carry less than 300 pounds, and llamas could carry up to 100 pounds. Heavy machinery, therefore, could not be transported on the backs of mules and llamas and investment was discouraged. Araoz (1889), for example, argued that the mining business required large concentration plants to reach its «maximum potential». However, the construction of concentration plants required large and heavy machinery, which was practically impossible to carry on the backs of mules and llamas (Deustua 2009, p. 210).

The lack of modern modes of transportation probably constituted a larger a barrier to trade as the demand for transportation increased. When the production levels were low, the needs for transportation were also low, and therefore the system of mules and llamas probably did not represent an important constraint to investment and economic growth. As more mines were exploited and more land was cultivated, the needs for transportation increased, and in this situation mules and llamas could not offer the same service as a more modern system of transportation. The scarcity of animals and arrieros led to the increase in freight rates and represented a significant obstacle to transportation. Nature eventually imposed a constraint on economic growth: the limited numbers of mules, llamas and arrieros were probably not large enough to support the increasing demand for transportation ${ }^{30}$.

However, although the comparison of transport costs between the pre-rail transport system, railroads and the sea, as well as the opinion of contemporary observers, represents valuable information, they do not constitute proof that the system of transportation of Peru represented a significant barrier to trade and economic growth. A more formal testing procedure is required to determine the impact of high transport costs on economic growth in Peru. In particular, testing whether the construction of railroads promoted economic growth may help to understand the economic impact of transport costs. Considering that transportation in most regions of Peru was conducted by mule and llama, if the construction of railroads promoted economic growth one might argue that the system of transportation in most of Peru limited the growth of the economy. Using the terminology employed

${ }^{30}$ In fact, had railroads not been built in Peru, it would have been physically impossible to transport the same tonnage as was transported by train. Deustua (2009) conducts a simulation to estimate the number of mules needed to replace the Central Railway. In 1890-1900, this railroad carried almost 104,000 metric tonnes per year. Assuming that mules completed ten round trips between Cerro de Pasco and Callao per year (around 200 days a year), around 100,000 mules would have been required annually during this period only to replace the Central Railway. If each mule completed only one round trip, one million mules would have been needed. Deustua indicates that this was an «unimaginable scenario» (Deustua 2009, p. 218). 
by Hausmann et al. (2005), if railroads promoted economic growth, then the lack of railroads in most of the country was a «binding constraint» to economic growth.

Some might question the validity of the argument that if railroads promoted economic growth then the lack of railroads was a binding constraint to economic growth. It is possible, for example, that only those regions with railroads had abundant natural resources. In this case, the construction of railroads in regions with no natural resources would not have fostered economic growth. The evidence, however, indicates that Peru had large endowments of natural resources throughout its territory, and not only in the areas served by railroads. For example, Ledesma and Bollaert (1856) indicated that Peru was

«... one of the richest countries in the world for the animal, vegetable and mineral wealth ... Peru produces, in its various climates, all the fruits, grain, and vegetables cultivated in different countries, independently of those which are indigenous; the latter including many of exquisite flavor. The transandine region is wonderful for the abundance and singularity of its productions. In its immense forests are ornamental woods in great variety, together with the Peruvian-bark tree, cocoa, coffee, coca, sarsaparilla, vanilla. The mineral kingdom of Peru is celebrated for placeres of gold and mines of silver, mercury, copper, lead, sulphur, and coal; as well as quarries of various marbles. Important are the gold placers of Carabaya the silver mines of Pasco, Puno, Guantajaya, and Gualgayoc; the mercury mines of Guancavelica and Chouta; the salt beds of Tarapaca, and the salt pits of Huacho and Sechura ...» (Ledesma and Bollaert 1856, pp. 217-218)

Similarly, Markham (1874) indicated that the Andes Mountains, «... contain inexhaustible stores of copper and silver, the plains afford pasture for large flocks of alpacas, while the inner slopes of the Eastern Andes produce the best Peruvian bark, coffee, cocoa, coca, arnotto, and are watered by streams containing gold-dust in large quantities» (Markham 1874, p. 127). Peru enjoyed the presence of abundant natural resources throughout its territory; therefore, it is reasonable to assume that if the railroad played a key role for economic growth of the regions it reached it would probably also have had a positive impact on the economic growth of other regions.

I use data on exports to estimate the impact of railroads on the economy. The construction of railroads and the consequent reduction in time and money transport costs probably led to the growth of market-oriented production, including production for foreign markets. Not all exports, however, would have been influenced by the construction of railroads to the same extent. Guano, for example, was extracted from coastal islands and transported directly to Europe by ship. Overland transportation facilities were not required for exporting guano. In contrast, crops from the coastal haciendas and 
minerals from the highland mines were transported to the sea ports by land, and thus the construction of railroads may have facilitated their transportation. In addition, in the case of mineral exports, Contreras (2004) indicates that the industry of copper was much more influenced by the construction of the Central Railway than the silver industry, because of differences in the value/ volume ratios. Copper exports tended to have a much lower value/volume ratio than silver exports, and thus the presence of scale economies in the transportation of minerals was larger in the case of copper. On the other hand, considering that the pre-rail costs for transporting crops from the coastal haciendas to the sea ports were probably lower than the costs for transporting minerals from the mines in the highlands, it is possible that the impact of the railroad was larger for the production of copper in the central highlands than for the production of cotton and sugar on the coast.

An econometric approach is used to test whether the length of the railway network had a significant statistical effect on the level of exports. In particular, the effect of the length of the railway track on the level of exports of the four main export products (copper, silver, sugar and cotton) in 1920 is estimated, as is the effect of the length of the Central Railway on the volume of copper and silver exports. The Central Railway connected the port of Callao, Lima and the mining centres of Junín and Cerro de Pasco and may have had a positive impact on the growth of mining exports. The effect of the length of coastal railroads on the volume of sugar and cotton exports is also estimated. Sugar and cotton had been produced mostly on the coast from colonial times, and thus the construction of railroads along the coast connecting haciendas, the main cities and ports may have impacted on the growth of cotton and sugar exports.

The following four variables measure the level of exports: COPPER is the natural log of the copper exports in metric tonnes, SILVER is the natural log of silver exports in metric tonnes, COTTON is the natural log of cotton exports in metric tonnes and SUGAR is the natural log of sugar exports in metric tonnes ${ }^{31}$. The following two variables measure the length of railroads: RAIL_CENTRAL is the natural log of the quantity of miles of the Central Railway and RAIL_COAST is the natural log of the quantity of miles of the railway system in coastal Peru. RAIL_CENTRAL may have a positive effect on SILVER and COPPER, whereas RAIL_COAST may have positive effect on COTTON and SUGAR.

Let us analyse the time properties of the series. Table 7 reports the statistics for the following unit-root tests: Dickey-Fuller, Augmented Dickey-Fuller and Perron. In all tests, the null hypothesis is that the series have unit roots. The table also reports the 5 per cent critical values. If the statistics are greater in absolute value than critical values, then at a 5 per cent significance level the null hypothesis that the series has a unit root cannot be accepted. In the case

31 Data on exports are taken from Hunt (1973). 
TABLE 7

UNIT ROOT TESTS

\begin{tabular}{|c|c|c|c|c|c|}
\hline & \multirow[b]{2}{*}{ Dickey-Fuller } & \multirow[b]{2}{*}{ Augmented Dickey-Fuller } & \multicolumn{2}{|c|}{ Perron } & \multirow[b]{2}{*}{ No. obs. } \\
\hline & & & $\mathbf{Z}_{\rho}$ & $\mathbf{Z t}$ & \\
\hline \multicolumn{6}{|l|}{ SILVER } \\
\hline Level & $-1.851(-2.898)$ & $-1.004(-2.899)$ & $-5.790(-13.620)$ & $-1.550(-2.898)$ & 90 \\
\hline$\Delta$ Level & $-12.783(-2.899)$ & $-7.591(-2.900)$ & $-113.001(-13.612)$ & $-12.952(-2.899)$ & 89 \\
\hline \multicolumn{6}{|l|}{ COPPER } \\
\hline Level & $-2.455(-2.898)$ & $-2.336(-2.899)$ & $-7.771(-13.620)$ & $-2.056(-2.898)$ & 90 \\
\hline$\Delta$ Level & $-13.811(-2.899)$ & $-11.754(-2.900)$ & $-107.040(-13.612)$ & $-15.154(-2.899)$ & 89 \\
\hline \multicolumn{6}{|l|}{ SUGAR } \\
\hline Level & $-0.350(-2.898)$ & $-0.051(-2.899)$ & $-0.380(-13.620)$ & $-0.285(-2.898)$ & 90 \\
\hline$\Delta$ Level & $-12.552(-2.899)$ & $-5.901(-2.900)$ & $-132.064(-13.612)$ & $-12.126(-2.899)$ & 89 \\
\hline \multicolumn{6}{|l|}{ COTTON } \\
\hline Level & $-2.067(-2.898)$ & $-1.802(-2.899)$ & $-5.036(-13.620)$ & $-1.801(-2.898)$ & 90 \\
\hline$\Delta$ Level & $-11.222(-2.899)$ & $-9.833(-2.900)$ & $-92.681(-13.612)$ & $-11.735(-2.899)$ & 89 \\
\hline \multicolumn{6}{|l|}{ RAIL_CENTRAL } \\
\hline Level & $-0.690(-2.914)$ & $-0.695(-2.915)$ & $-1.026(-13.460)$ & $-0.662(-2.914)$ & 70 \\
\hline$\Delta$ Level & $-8.394(-2.915)$ & $-5.992(-2.916)$ & $-68.827(-13.452)$ & $-8.400(-2.915)$ & 69 \\
\hline \multicolumn{6}{|l|}{ RAIL_COAST } \\
\hline Level & $-1.783(-2.914)$ & $-1.801(-2.915)$ & $-2.014(-13.460)$ & $-1.645(-2.914)$ & 70 \\
\hline$\Delta$ Level & $-7.171(-2.915)$ & $-3.644(-2.916)$ & $-69.996(-13.452)$ & $-7.371(-2.915)$ & 69 \\
\hline
\end{tabular}

Notes: The table reports Dickey-Fuller, Augmented Dickey-Fuller (with one lag) and Perron statistics for several models. Null hypothesis is that the variable has a unit root. $5 \%$ critical value are in parenthesis. 
TABLE 8

JOHANSEN COINTEGRATION TEST

\begin{tabular}{|c|c|c|c|c|}
\hline Rank & Null hypothesis & $\begin{array}{c}\text { Log- } \\
\text { likelihood }\end{array}$ & \begin{tabular}{|c|} 
Trace \\
statistic
\end{tabular} & $\begin{array}{l}5 \% \text { critical } \\
\text { value }\end{array}$ \\
\hline \multicolumn{5}{|c|}{$\begin{array}{l}\text { Variables: SILVER and } \\
\text { RAIL-CENTRAL }\end{array}$} \\
\hline 0 & $\begin{array}{l}\text { There is no } \\
\text { cointegration vector }\end{array}$ & -20.93 & 10.97 & $15.41 *$ \\
\hline 1 & $\begin{array}{l}\text { There is at most one } \\
\text { cointegration vector }\end{array}$ & -16.09 & 1.28 & 3.76 \\
\hline \multicolumn{5}{|c|}{$\begin{array}{l}\text { Variables: COPPER and } \\
\text { RAIL-CENTRAL }\end{array}$} \\
\hline 0 & $\begin{array}{l}\text { There is no } \\
\text { cointegration vector }\end{array}$ & -1.56 & 5.86 & $15.41^{*}$ \\
\hline 1 & $\begin{array}{l}\text { There is at most one } \\
\text { cointegration vector }\end{array}$ & -1.37 & 0.00 & 3.76 \\
\hline \multicolumn{5}{|c|}{$\begin{array}{l}\text { Variables: SUGAR and } \\
\text { RAIL-COAST }\end{array}$} \\
\hline 0 & $\begin{array}{l}\text { There is no } \\
\text { cointegration vector }\end{array}$ & 59.79 & 13.39 & $15.41 *$ \\
\hline 1 & $\begin{array}{l}\text { There is at most one } \\
\text { cointegration vector }\end{array}$ & 66.13 & 0.70 & 3.76 \\
\hline \multicolumn{5}{|c|}{$\begin{array}{l}\text { Variables: COTTON and } \\
\text { RAIL-COAST }\end{array}$} \\
\hline 0 & $\begin{array}{l}\text { There is no } \\
\text { cointegration vector }\end{array}$ & 22.88 & 6.51 & $15.41^{*}$ \\
\hline 1 & $\begin{array}{l}\text { There is at most one } \\
\text { cointegration vector }\end{array}$ & 26.11 & 0.06 & 3.76 \\
\hline
\end{tabular}

Notes: The table reports the statistics for a Johansen cointegration test. All vector-correction models include ten lags for the endogenous variables in first differences.

*Acceptance of the null hypothesis.

of the series in levels, the statistics are lower in absolute value than the critical values; in the case of the series in differences, the statistics are greater in absolute value than the critical values. Therefore, all series in our data are integrated of first-order, or I(1).

The Johansen method is used to test cointegration. If two series are cointegrated, then the Johansen test indicates the existence of at least one cointegrating vector. Table 8 reports the Johansen statistics for the following hypotheses: there is no cointegrating vector, and there is at least one cointegrating vector. Critical values at a 5 per cent significance level are also 
TABLE 9

GRANGER TEST OF CAUSALITY

\begin{tabular}{|l|c|c|c|c|}
\hline Model & Dependent variable & Possible cause & $\chi^{2}$ & Probability \\
\hline Model 1 & D(COPPER) & D(RAIL-CENTRAL) & 27.780 & 0.002 \\
& D(RAIL-CENTRAL) & D(COPPER) & 32.416 & 0.000 \\
\hline Model 2 & D(SILVER) & D(RAIL-CENTRAL) & 13.000 & 0.224 \\
& D(RAIL-CENTRAL) & D(SILVER) & 2.622 & 0.989 \\
\hline Model 3 & D(SUGAR) & D(RAIL-COAST) & 27.565 & 0.002 \\
& D(RAIL-COAST) & D(SUGAR) & 116.030 & 0.000 \\
\hline \multirow{2}{*}{ Model 4 } & D(COTTON) & D(RAIL-COAST) & 34.057 & 0.000 \\
& D(RAIL-COAST) & D(COTTON) & 36.083 & 0.000 \\
\hline
\end{tabular}

Notes: The table reports Granger statistics and $P$-values. All vector autoregression models include 10 lags for the dependent variables and WAR lagged one year.

reported. I evaluate whether the following pairs of series are cointegrated: COPPER and RAIL-CENTRAL, SILVER and RAIL-CENTRAL, COTTON and RAIL-COAST and SUGAR and RAIL-COAST ${ }^{32}$. In all cases, at a 5 per cent level the null hypothesis that the series are not cointegrated cannot be rejected. There does not seem to be a long-term relationship between the level of exports of the four main Peruvian export products and the length of the railway network.

A vector autoregression model for the variables in first differences is then estimated to determine whether the length of the railroad network promoted the growth of exports ${ }^{33}$. Ten lags are included to capture the long-term lagged effects. A Granger test was conducted to determine the causality relationship. Table 9 reports the results for the Granger test, and the results for Model 1 indicate that D(RAIL-CENTRAL) caused D(COPPER) and $\mathrm{D}$ (COPPER) causes $\mathrm{D}$ (RAIL-CENTRAL). A faster growth of railway length increased the growth of copper exports. However, a faster growth of copper exports also promoted the construction of the Central Railway. On the other hand, the results for Model 2 indicate that the impact of railway construction on silver exports and vice versa did not seem important. The Granger test

${ }^{32}$ Ten lags have been chosen in all cases, although the results are similar for other lag specifications.

${ }_{33} \mathrm{D}$ (COPPER) is COPPER in first differences, D(SILVER) is SILVER in first differences, $\mathrm{D}$ (SUGAR) is SUGAR in first differences, $\mathrm{D}(\mathrm{COTTON})$ is COTTON in first differences, D(RAILCENTRAL) is RAIL-CENTRAL in first differences and D(RAIL-COAST) is RAIL-COAST in first differences. I also include a war dummy variable lagged one year to control for the economic effects of the War of the Pacific (1879-1883). 
TABLE 10

EFFECT OF AN INCREASE OF 1\% IN RAILWAY LENGTH ON THE LEVEL OF EXPORTS

\begin{tabular}{|l|c|c|c|}
\hline Exports & Railroad & Period & Effect (\%) \\
\hline Copper & Central Railway & After 5 years & 0.00 \\
& & After 10 years & 0.70 \\
\hline Silver & Central Railway & After 5 years & 0.00 \\
& & After 10 years & 0.00 \\
\hline Sugar & Coastal Railroads & After 5 years & 0.85 \\
& & After 10 years & 0.78 \\
\hline Cotton & Coastal Railroads & After 5 years & 0.14 \\
& & After 10 years & 0.14 \\
\hline
\end{tabular}

Notes: The table reports the estimated effect of a $1 \%$ shock to the level of railroad length on the level of exports after 5 and 10 years. The estimates have been obtained using the significant coefficients from the impulse-response functions.

indicates that D(RAIL_CENTRAL) did not cause D(SILVER) and D(SILVER) did not cause D(RAIL_CENTRAL). The impulse-response functions consistently indicate that these variables did not cause each other. Cotton and sugar exports were also influenced by railway length. The results for Model 3 indicate that D(SUGAR) and D(RAIL-COAST) also cause each other. From the impulse-response functions, a shock to D(RAIL-COAST) has significant effects on D(SUGAR) after 3, 5 and 10 years, but a negative effect after 4 years. The results for Model 4 indicate that $\mathrm{D}(\mathrm{COTTON})$ and $\mathrm{D}$ (RAIL-COAST) caused each other. The impulse-response function indicates that a shock to D(RAIL-COAST) had a positive and statistically significant effect on $\mathrm{D}(\mathrm{COTTON})$ after 2 years.

Table 10 simulates the evolution of exports assuming a shock of 1 per cent to the railroad length in year $\tau$. The table reports the ratio of predicted exports with respect to actual exports for years $\tau+5$ and $\tau+10$. I used the coefficients from the impulse-response functions and calculated the ratio using the following formula: $y_{\tau+k}=\prod_{j=1}^{k}\left[1+\theta_{j}(1 \%)\right]$ for $k=5,10$, where $y_{\tau+k}$ is the ratio of predicted exports with respect to actual exports in the year $\tau+k$ assuming a shock of 1 per cent to the railroad length in year $\tau$. $\theta_{j}$ is the coefficient of the impulse-response function and measures the response of the natural log of the level of exports (in first differences) to a shock to the natural log of railroad length (in first differences) after $j$ years. Using the significant coefficients from the impulse-response functions, the results indicate that copper, sugar and cotton exports responded to shocks to the railroad length. In the case of mining exports, predicted copper exports were 
0.7 per cent greater than actual copper exports after 10 years, as a result of a shock of 1 per cent to the length of the Central Railway. However, predicted silver exports were the same as actual exports: silver exports did not respond to shocks to the length of the Central Railway. In the case of agricultural exports, sugar and cotton exports responded to railroad construction on the coast. Predicted sugar exports were greater than actual sugar exports by 0.78 per cent after 10 years, whereas predicted cotton exports were 0.14 per cent greater than actual cotton exports also after 10 years.

These results suggest that the construction of railroads had a positive effect on the growth of exports. In particular, the railroad promoted the extraction and exportation of copper, cotton and sugar. One implication of the econometric results is that if more railroads had been built, the growth of exports would have been greater during this period. Therefore, as argued by Pardo in 1860 (McEvoy 2004), and Dávalos y Lissón in 1919 (Dávalos y Lissón 1919), among several contemporary observers, the absence of lowcost modes of transportation in most of Peru retarded economic growth.

\section{CONCLUSIONS}

This paper analyses the system of transportation and explores the impact of geography and infrastructure on transport costs and economic growth in Peru in the $19^{\text {th }}$ and early $20^{\text {th }}$ centuries. Using primary and secondary sources, I show that geography imposed difficult transport challenges for Peruvians during this period. The coast imposed high barriers to overland transportation as the sandy desert made travelling difficult and exhausting, whereas the highlands and their steep, narrow roads made travelling extremely risky and challenging. In addition, Peru did not have navigable rivers in coastal and highland regions and most roads were inadequate for wagons.

Railroad construction began in the mid-19 $9^{\text {th }}$ century but was, however, a very slow process. In the early $20^{\text {th }}$ century, Peru was far behind other countries in the region. On the coast, railroads connected only a few cities and valleys. Only two railway systems linked the coast and the highlands: the Central Railway, which connected Callao, Lima and the mines of Junin and Pasco; and the Southern Railway, which ran between Arequipa, Puno and Cuzco. Moreover, monopoly power (together with inefficient government regulation) and the abrupt nature of the Peruvian landscape led to high rail freight rates.

Most transportation at the time was conducted on the backs of mules and llamas. This system was associated with high time and money transport costs, in comparison to railroads and waterways. Freight rates were especially high as the needs for transportation and the demand for mules and llamas increased. For instance, as the production of copper started to boom in the central highlands in the late 1890s, freight rates increased drastically. The scarcity of mules, llamas and arrieros led to significant increases in the 
price of transportation. In such circumstances, it seems that the traditional system of overland transportation using mules and llamas represented an obstacle to economic growth.

Employing econometric techniques, I find that the construction of railroads promoted the growth of the exporting economy. In the highlands, the construction of the Central Railway promoted the growth of copper exports. On the coast, the expansion of the railway system promoted the growth of sugar and cotton exports. This result is crucial for explaining the slow growth of the Peruvian economy. Since railroads had a positive impact on production and exports, the lack of railroads in other coastal, highland and jungle regions of Peru probably retarded trade and economic growth. High transportation costs were then a binding constraint to growth in most of Peru.

Some might argue that it is not possible to extrapolate the positive role of railroads in the copper, sugar and cotton sectors. It is possible that regions without railroads did not have other factors that favoured economic growth. In this case, the construction of railroads would have not promoted economic growth in those areas, and thus the traditional system of transportation did not represent a binding constraint to economic growth. Contemporary evidence, however, suggests that Peru had other favourable conditions for growth. Natural resources, for example, were abundant in other regions. It is possible then that if railroads had been built throughout the country, the reduction in transport costs would have led to increases in trade, gains from specialisation and economic growth.

\section{REFERENCES}

AraOz, J. (1889): Excursión a Hualgayoc. AUNI, tesis No. 25, May.

Bonilla, H. (1976): Gran Bretaña y el Perú. Los Mecanismos de un Control Económico. Lima: Instituto de Estudios Peruanos, Fondo del Libro del Banco Industrial del Peru.

BRICEÑo Y Salinas, S. (1927): Cuadro General para el Término de Distancia Judicial, Civil y Militar dentro de la República y aun en el extranjero. Lima: Imprenta Americana.

Bulmer-Thomas, V. (2003): The Economic History of Latin America since Independence. Cambridge: Cambridge University Press.

Cisneros, C. (1906): Reseña Económica del Perú. Lima: Imprenta «La Industria».

CoAtsworth, J. (1979): «Indispensable Railroads in a Backward Economy: The Case of Mexico». The Journal of Economic History 39 (4), pp. 939-960.

Contreras, C. (2004): El aprendizaje del capitalismo. Estudios de historia económica y social del Perú Republicano. Lima: IEP.

Costa Y Laurent, F. (1908): Reseña Histórica de los Ferrocarriles del Perú. Lima: Ministerio de Fomento, Litografía Tip. Carlos Fabbri.

Crafts, N., and Mulatu, A. (2006): «How Did the Location of Industry Respond to Falling Transport Costs in Britain before World War I?». Journal of Economic History 66 (3), pp. 575-607.

Dávalos Y Lissón, P. (1919): La Primera Centuria. Lima: Librería e Imprenta Gil.

Denegri, F. (1976): La República. Lima: Instituto de Estudios Histórico-Marítimos del Perú. 
Deustua, J. (2009): El embrujo de la plata. La economía social de la minería en el Perú del siglo XIX. Lima: BCRP, IEP.

Dobado, R., and Marrero, G. (2005): "Corn Market Integration in Porfirian Mexico». Journal of Economic History 65 (1), pp. 103-128.

Eaton, J., and Kortum, S. (2002): «Technology, Geography and Trade». Econometrica 70 (5), pp. 1741-1779.

Espinosa, C. (2002): «Entre la Ciudad y el Continente: Opciones para la construcción de los Estados Andinos en la Epoca de la Independencia», Revista Andina, No. 34. Lima: Centro de Estudios Regionales Andinos Bartolomé de las Casas, pp. 155-183.

Fishlow, A. (1965): American Railroads and the Transformation of the Ante-Bellum Economy. Cambridge: Harvard University Press.

Flores, A. (1993): "Arequipa y el Sur Andino», in Obras Completas, vol. I, Lima: Fundación Andina, SUR Casa de Estudios del Socialismo, pp. 231-452.

Fogel, R. (1962): «A Quantitative Approach to the Study of Railroads in American Economic Growth: A Report of Some Preliminary Findings». The Journal of Economic History 22 (2), pp. 163-197.

Fogel, R. (1964): Railroads and American Economic Growth: Essays in Econometric History. Baltimore: The Johns Hopkins Press.

Fogel, R. (1979): «Notes on the Social Savings Controversy». The Journal of Economic History 39 (1), The Tasks of Economic History, March, 1-54.

Fremdling, R. (1977): «Railroads and German Economic Growth: A Leading Sector Analysis with a Comparison to the United States and Great Britain». The Journal of Economic History 37 (3), pp. 583-604.

Galessio, E. (2007): Ferrocarriles del Perú. Un viaje a través de su historia. Lima: Tarea Gráfica Educativa.

Gallup, J.; Sachs, J., and Mellinger, A. (1999): "Geography and Economic Development», in B. Pleskovic, and J. Stiglitz (eds), Annual World Bank Conference on Development Economics, 1998. Washington, DC: World Bank.

Garland, A. (1901): Artículos Económicos publicados en El Comercio. Lima: Imprenta La Industria.

Gómez, J., and BazÁN, I. (1989): Capitalismo y Formación Regional. Chiclayo entre los siglos $X I X$ y XX. Chiclayo: Población y Desarrollo, Instituto de Investigación y Capacitación.

Gootenberg, P. (1990): "Carneros y Chuño: Price Levels in Nineteenth-Century Peru». The Hispanic American Historical Review 70 (1), pp. 1-56.

Hausmann, R.; Rodrik, D., and Velasco, A. (2005): Growth Diagnostics. Cambridge: Harvard University, Kennedy School (manuscript).

Hawke, G. (1970): Railways and Economic Growth in England and Wales, 1840-1870. London: Oxford University Press.

Hills, S. S. (1860): Travels in Peru and Mexico, vols. I and II, London: Longman, Green, Longman and Roberts.

HoERnel, R. (1976): «Sugar and Social Change in Oriente, Cuba, 1898-1946». Journal of Latin American Studies 8 (2), pp. 215-249.

Hunt, S. (1973): «Price and Quantum Estimates of Peruvian Exports, 1830-1962». Discussion Paper No. 33, Princeton: Princeton University.

Jones, C. (1927): «The Commercial Growth of Peru». Economic Geography 3 (1), pp. 23-49.

Ledesma, V., and Bollaert, W. (1856): "Outlines of the Geography of Peru». Journal of the Royal Geography Society of London 26, pp. 210-229.

LefF, N. (1972): «Economic Retardation in Nineteenth Century Brazil». The Economic History Review, New Series 25 (3), pp. 489-507.

Lemale, C. (1876): Almanaque de Comercio de Lima 1876. Lima: Imprenta del Estado. 
Markham, C. (1874): «Railroad and Steam Communication in Southern Peru». Journal of the Royal Geography Society of London 44, pp. 127-132.

Mattoon, R. (1977): «Railroads, Coffee and the Growth of Big Business in Sao Paulo, Brazil». The Hispanic American Historical Review 57 (2), pp. 273-295.

McGreevey, W. (1971): An Economic History of Colombia, 1850-1930. Cambridge: Cambridge University Press.

McEvoy, C. (2004): La Huella Republicana Liberal en el Perú. Manuel Pardo. Escritos fundamentals. Lima: Fondo Editorial del Congreso del Perú.

Metzer, J. (1974): «Railroad Development and Market Integration: The Case of Tsarist Russia». The Journal of Economic History 34 (3), pp. 529-550.

Middenford, E. (1974): Perú. Observaciones y Estudios del País y sus Habitantes durante su permanencia de 25 años. Lima: Universidad Nacional Mayor de San Marcos.

Miller, R. (1976): «Railways and Economic Development in Central Peru, 1890-1930», in R. Miller, C. Smith, and J. Fisher (eds), Social and Economic Change in Modern Peru. Center for Latin American Studies, Liverpool: University of Liverpool.

Milstead, H. (1928): «Distribution of crops in Peru». Economic Geography 4 (1), pp. 88-106.

Overman, H.; Redding, S., and Venables, A. (2003): «The Economic Geography of Trade, Production and Income: a Survey of Empirics», in E. Choi and J. Harrigan (eds), Handbook of International Trade, Blackwell Handbooks in Economics. Malden: Blackwell Publishing, pp. 353-387.

Pinto, M., and Salinas, A. (2009): Las rutas del café y el trigo. Los ferrocarriles de Chanchamayo y Huancavelica 1886-1932, Seminario de Historia Rural Andina. Lima: Universidad Nacional Mayor de San Marcos.

Price, R. (1975): The economic modernization of France, 1770-1830. London: Redwood Burn Ltd.

Quiroz, A. (1993): Domestic and Foreign Finance in Modern Peru, 1850-1950, Financing Visions of Development. Pittsburgh: University of Pittsburgh Press.

Raimondi, A. (2006): El Departamento de Ancash. Lima: Universidad Nacional Mayor de San Marcos.

República del Perú, Ministerio de Fomento (1940): Extracto Estadístico del Perú, 1939. Lima: Imprenta Americana, Casa Editora La Opinión Nacional.

Rousslang, D., and To, T. (1993): «Domestic Trade and Transportation Costs as Barriers to International Trade». The Canadian Journal of Economics 26 (1), pp. 208-221.

Rostow, W. (1962): The Process of Economic Growth. New York: W.W. Norton \& Company, Inc.

Stevenson, W. B. (1825): Historical Descriptive Narrative of Twenty Years Residence in South America. London: Hurst, Robinson and Co.

Summerhill, W. (2005): «Big Social Savings in a Small Laggard Economy: Railroads-Led Growth in Brazil». Journal of Economic History 65 (1), pp. 72-102.

Tizón, R. (1909): Algunos artículos sobre vialidad nacional. Lima: Tipografía Nacional Pedro Berrio.

Tschudi, Von J. J. (1847): Travels in Peru during the years 1838-1842 on the coast, in the sierra, across the cordillera and the Andes, into the Primeval Forests. London: David Bogue.

VAmplew, W. (1971): "Railways and the Transformation of the Scottish Economy». Economic History Review 24 (1), pp. 37-54.

Vega, A., and Sulca, J. (2005): Arrieros Huamanguinos. Huamanga: San Juan Bautista.

Waszkis, H. (1993): Mining in the Americas: Stories and History. Abington, Cambridge: Woodhead Publishing Limited.

Wortley, E. S. (1851): Travels in the United States, etc. during 1849 and 1850. London: Richard Bentley. 